\title{
EFFECT OF DIETARY LIPID CONTENTS ON GROWTH OF ESTUARY GROUPER, Epinephelus coioides JUVENILES
}

\author{
Ketut Suwirya"', Nyoman Adiasmara Giri", Agus Prijono"), and Muhamad Marzuqi'
}

\begin{abstract}
Lipid is dietary component for energy and essential fatty acid sourced. Requirement of lipid for fish varies depending on species and size. The present study was conducted to evaluate the levels of dietary lipid on growth of estuary grouper Epinephelus coioides juveniles. Twelve fish of $5.0 \pm 0.3$ grams in body weight were reared in 30 liter tanks for 77 days with water flow through system. Temperature and salinity of the rearing water ranged between $28-30^{\circ} \mathrm{C}$ and $31-33 \mathrm{ppt}$, respectively. The levels of lipid in the test diets were $0.0 \%$, $3.0 \%, 6.0 \%, 9.0 \%, 12.0 \%$, and $15.0 \%$. The results of experiment showed that dietary lipid affected growth and feed efficiency of estuary grouper juveniles. Juveniles of estuary grouper fed with $3.0 \%-12 \%$ dietary lipid had higher growth rate than fish fed diet without lipid, but increasing dietary lipid from $12 \%$ to $15 \%$ reduced the growth of fish $(P<0.05)$. The optimum level of dietary lipid for estuary grouper juveniles was $12 \%$. The specific growth rate and feed efficiency of juveniles fed with $0.0 \%, 3.0 \%, 6.0 \%, 9.0 \%, 12.0 \%$, and $15 \%$ of dietary lipid were $1.908,2.017,2.001,2.038,2.069,1.996$, and $0.82,0.97,1.10,1.10,1.08,1.07$, respectively.
\end{abstract}

KEYWORDS: $\quad$ estuary grouper, lipid, and growth

\section{INTRODUCTION}

At present, estuary grouper (Epinephelus coioides) breeding has been succeded and need to continue in development to support mariculture. One the important factor is feed research for estuary grouper to anticipate its culture. Important feed component for carnivorous fish is lipid, that serves energy and essential fatty acids sources to support the growth of red sea bream (Vergara et al, 1996). Dietary lipid content affected growth of red drum fish (Williems \& Robinson, 1988) and humpback grouper (Giri et al., 1999). Utilization of lipid by fish reduces the use of dietary protein in metabolism. Other important factor for lipid is fatty acid composition of lipid sources used in feed.

Most of marine fish has limited ability to synthesize n-3 HUFA from n-3 short chain fatty acids (Owen et al., 1975; Kanazawa et al., 1979; Ostrowski \& Divakaran, 1990). N-3 HUFA such as 20:5n-3 (EPA) and $22: 6 n-3$ (DHA) are essential fatty acids for most marine fish (Yano \& Fujii, 1975, Fujita et al., 1980; Watanabe et al. 1983; izquierdo et al., 1989; Webster \& Lovell, 1990). Lack of dietary n-3 HUFA causes high mortality, slow growth and unperfected development of swim bladder for fish larvae (Sorgeloos et al. 1988; Webster \& Lovell, 1990; Koven et al., 1990). Salhi et al. (1994) reported that the content of dietary n-3 HUFA $2,05-2,16 \%$ in microdiet had better survival rate than content of dietary n-3 HUFA $0,74-0,82 \%$ for gilthead sea bream larvae.

Ability of fish to use dietary lipid depends on species. Due to that reason, this experiment was conducted to know dietary lipid requirement for estuary grouper

\section{MATERIAL AND METHODS}

Dietary protein sources of this experiment such as fish, tinny shrimp, and squid liver meal were extracted by method Bligh \& Dryer (1959) to reduce lipid content. Experimental diets were formulated with different lipid contents. Equal energy content in each diet was adjusted by dextrin. Energy content of dextrin is half of fish oil energy (Williams \& Robinson, 1988). Composition of experimental diets is shown in Table 1.

Dietary lipid contents in this experiment were $0.0 \%, 3.0 \%, 6.0 \% \quad 9.0 \%, \quad 12.0 \%$, and $15.0 \%$, respectively. This experiment was done in CRD with six treatments and three replicates.

Hatchery produced juvenile of estuary grouper, 5.0 \pm 0.3 gram in average body weight were stocked in 30 liters polycarbonate tanks with density of 12 fish per tank. Each tank was equipped with flow through system and aeration to maintain water quality in rearing tank. Water flow rate was $200 \mathrm{ml}$ per minute. Water temperature and salinity during the experiment were $28-29^{\circ} \mathrm{C}$ and $31-33 \mathrm{ppt}$, respectively. Fish were fed twice daily to satiation.

Body weight and survival were recorded every week for 11 weeks. At the end of the experiment, a representative sample of fish from each tank was dried and chemical composition of fish was determined. Crude protein, lipid and ash content of diets and fish were analyzed following the standard methods of AOAC (1990). The growth, feed efficiency, protein efficiency as well as protein and lipid retention data were analyzed using one way ANOVA and differences between treatments were considered significant at $\mathrm{P}<0.05$ (Steel \& Torrie, 1980).

Research Institute for Mariculture, Gondol (Bali) 
Table 1. Composition of law material and nutrient the experimental diets (\%)

\begin{tabular}{|c|c|c|c|c|c|c|}
\hline \multirow[t]{2}{*}{ Ingredients } & \multicolumn{6}{|c|}{ Dietary lipid (\%) } \\
\hline & 0.0 & 3.0 & 6.0 & 9.0 & 12.0 & 15.0 \\
\hline Casein & 20.0 & 20.0 & 20.0 & 20.0 & 20.0 & 20.0 \\
\hline Fish meal & 36.0 & 36.0 & 36.0 & 36.0 & 36.0 & 36.0 \\
\hline Squid meal & 4.0 & 4.0 & 4.0 & 4.0 & 4.0 & 4.0 \\
\hline Krill meal & 2.9 & 2.9 & 2.9 & 2.9 & 2.9 & 2.9 \\
\hline Mineral mix & 1.7 & 1.7 & 1.7 & 1.7 & 1.7 & 1.7 \\
\hline Vitamın $\mathrm{mix}^{2}$ & 1.3 & 1.3 & 1.3 & 1.3 & 1.3 & 1.3 \\
\hline Carophylpink & 0.1 & 0.1 & 0.1 & 0.1 & 0.1 & 0.1 \\
\hline $\mathrm{CMC}$ & 2.0 & 2.0 & 2.0 & 2.0 & 2.0 & 2.0 \\
\hline Wheat flour & 2.0 & 2.0 & 2.0 & 2.0 & 2.0 & 2.0 \\
\hline Dextrin & 30.0 & 24.0 & 18.0 & 12.0 & 6.0 & 0.0 \\
\hline Fish oil & 0.0 & 3.0 & 6.0 & 9.0 & 12.0 & 15.0 \\
\hline Cellulose & 0.0 & 3.0 & 6.0 & 9.0 & 12.0 & 15.0 \\
\hline \multicolumn{7}{|l|}{ Analysis } \\
\hline Crude protein & 47.71 & 48.12 & 47.51 & 48.21 & 47.63 & 48.17 \\
\hline Crude lipid & 1.10 & 4.12 & 7.50 & 10.21 & 13.70 & 16.21 \\
\hline Fiber & 2.13 & 4.21 & 5.91 & 8.30 & 11.29 & 14.47 \\
\hline Ash & 7.64 & 7.72 & 7.65 & 7.66 & 7.58 & 7.58 \\
\hline $\mathrm{N}$-free extract & 32.73 & 27.4 & 20.7 & 14.5 & 7.5 & 1.8 \\
\hline Energy $(\mathrm{Kcal} / \mathrm{g} \mathrm{diet})^{3}$ & 4.99 & 4.97 & 5.00 & 4.98 & 5.00 & 4.99 \\
\hline
\end{tabular}

Vitamin Mix (mg/100 gram diet): thiamin- $\mathrm{HCl}, 5.0$; riboflavin, 5.0; Ca-pantothenate, 10.0; niacin, 2.0; pyridoxin- $\mathrm{HCl}, 4.0 ;$ biotin, $0.6 ;$ folic acid, 1.5; cyanocobalamin, 0.01; inositol, 200; p-aminobenzoic acid, 5.0; menadion, 4,0; b-carotin, 15.0; calciferol, 1.9; a-tocopherol, 250 ; vitamin C (phosphitan), 120; choline chloride, 900.

Mineral mix (mg/100 gram diet): KH2PO4, 412; CaCO4, 282; Ca(H2PO4), 618; FeCl2, 166; ZnSO4, 9.99; MnSO4, 6.3; CuSO4, 2; CoSO 4, 0.05; KJ. 0.15 .

${ }^{3}$ Total energy based on energy content of protein $=5.65 \mathrm{Kcal} / \mathrm{g} ;$ lipid $=9.45 \mathrm{Kcal} / \mathrm{g} ;$ carbohydrate, $4.10 \mathrm{kcal} / \mathrm{g}$ )

\section{RESULTS AND DISCUSSION}

Growth of estuary grouper juvenile every 7 days for each treatment is shown in Figure 1. Estuary grouper juveniles fed dietary lipid $0 \%$ showed delay body weight development compared to other treatments in 49 days rearing period (Figure 1). Fish fed dietary lipid $0 \%$ and $3 \%$ was observed with delayed growth compared to fish fed dietary lipid 6\%, $9 \%$, and $12 \%$ in 56 days experiment. Figure 1 showed that dietary lipid has role to support growth of estuary grouper juveniles.

Specific growth rate, feed efficiency, and feed consumption at the end of the experiment were shown in Table 2 . Fish fed dietary lipid $0 \%$ has lower specific growth rate than fish fed dietary lipid from $3 \%$ to $12 \%$ $(\mathrm{P}<0.05)$. Increased dietary lipid from $3 \%$ to $12 \%$ has trend of increasing growth of estuary grouper juveniles, but dietary lipid increased from $12 \%$ to $15 \%$ has trend of reduced specific growth rate (Table 2 ). This experiment showed that dietary $12 \%$ is an optimum for growth of estuary grouper juveniles.

Dietary lipid affected feed efficiency on estuary grouper juveniles (Table 2). Estuary grouper juveniles fed diet with $0 \%$ lipid had lower feed efficiency than fish fed diets with $3 \%$ and $6 \%$ lipid $(P<0.05)$. The others fed diets from $6 \%$ to $15 \%$ lipid had same feed efficiency $(P>0.05)$. This experiment showed that dietary lipid has to be considered in feed formulation of estuary grouper to increase feed efficiency. On other hand, dietary lipid has rule as sparing partner of protein.

Dietary lipid requirement varies with species Some results of experiments showed that Labio rohita of 7.5 gram in size had the best growth fed $6 \%$ dietary lipid (Gangadhara et al., 1997). Lipid requirement of sea bass (Lates calcacifer) and Morone chrysops of 4.5 gram in size were $12-18 \%$ (Cacutan \& Coloso, 1997), and 13\% (Gallagher, 1997), respectively Ernullah \& Jufri (1998a) reported that Calta calta dan Labio rohita had a maximum growth fed $36 \%$ dietary carbohydrate and $4 \%$ dietary lipid. Requirement of dietary carbohydrate and lipid for Cirrhinus mrigala fish were $27 \%$ and $8 \%$, respectively.

The best dietary lipid for catfish (Clarias batrachus) was $8 \%$ (Ernullah \& Jufri, 1998b). The other concern is the lipid source in feed formulation. Lipid source affects fish growth and feed efficiency. Tucker et al., (1997) reported that red drum only utilized $1.5 \%$ dietary soybean oil and $12.7 \%$ dietary menhaden oil. Other report on humpback grouper shown that this fish had better growth rate when they were fed dietary squid oil compared to soybean oil (Suwirya et al., 1999). 


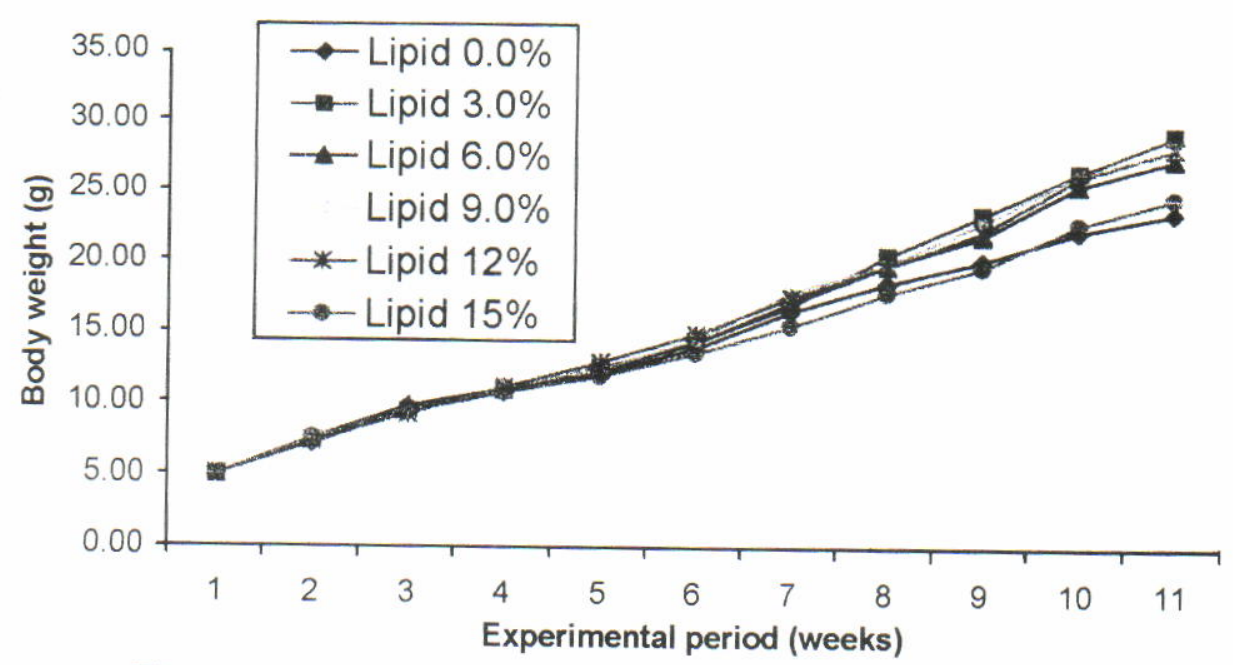

Figure 1. Growth of estuary grouper juveniles during the experiment

Table 2. Specific growth rate, feed efficiency ratio, and feed intake of estuary grouper juvenile fed different dietary lipid levels

\begin{tabular}{cccc}
\hline Dietary lipid (\%) & $\begin{array}{c}\text { Specific growth rate } \\
(\mathrm{G})^{1}\end{array}$ & Feed efficiency & Feed intake (gram/ind) \\
\hline 0.0 & $1.908 \pm 0.0023^{\mathrm{a}}$ & $0.82 \pm 0.0210^{\mathrm{a}}$ & $22.04 \pm 0.86^{\mathrm{a}}$ \\
3.0 & $2.017 \pm 0.068^{\mathrm{bc}}$ & $0.97 \pm 0.0493^{\mathrm{b}}$ & $23.80 \pm 2.97^{\mathrm{a}}$ \\
6.0 & $2.001 \pm 0.072^{\mathrm{bc}}$ & $1.00 \pm 0.0813^{\mathrm{bc}}$ & $20.38 \pm 3.85^{\mathrm{a}}$ \\
9.0 & $2.038 \pm 0.002^{\mathrm{bc}}$ & $1.10 \pm 0.0587^{\mathrm{c}}$ & $20.90 \pm 0.84^{\mathrm{a}}$ \\
12.0 & $2.069 \pm 0.014^{\mathrm{c}}$ & $1.08 \pm 0.0299^{\mathrm{c}}$ & $21.45 \pm 2.20^{\mathrm{a}}$ \\
15.0 & $1.996 \pm 0.031^{\mathrm{ab}}$ & $1.01 \pm 0.0412^{\mathrm{bc}}$ & $19.25 \pm 2.31^{\mathrm{a}}$ \\
\hline Mean in column with the same superscript are not significantly different $(P>0.05)$
\end{tabular}

${ }^{1} G=\left(\left(\ln W_{t}-\ln W_{0}\right) / t\right.$, where $G=$ Specific growth rate, Wo $=$ Initial body weight, $W t=$ End of body weight, $t=$ period of experiment $($ days $)$

Grouper, E. areolatus fed $10 \%$ dietary lipid and $60 \%$ protein had the best growth (Chu et al., 1996). The result of this experiment showed that estuary grouper (E. coioides) juveniles fed $12 \%$ dietary lipid and $48 \%$ dietary lipid had optimum growth.

Dietary lipid affected efficiency and retention protein on estuary grouper juveniles (Table 3 ). Juveniles fed dietary lipid from $6-15 \%$ had better efficiency protein compared to those fed 0-3\% dietary lipid $(P<0.05)$. Dietary lipid from $6-15 \%$ had the same efficiency protein on estuary grouper juveniles $(P>0.05)$.

Table 3.
Estuary grouper fed $6 \%$ dietary lipid had better protein retention than those fed from $0-3 \%$ dietary protein $(P<0.05)$. This experiment showed that estuary grouper juveniles fed $0-3 \%$ dietary lipid used higher protein for metabolism energy than those fed $6 \%$ dietary lipid.

Dietary lipid from 0-15\% did not affect protein, ash, and fiber of body composition but dietary lipid tended to increase body lipid (Table 4). The same result was shown with stripped bass fed $8 \%$ and $12 \%$ dietary lipid for 9 weeks caused increasing body lipid significantly (Fair et al., 1993).

\begin{tabular}{ccc}
\hline Dietary lipid (\%) & Protein efficiency $(\%)^{*}$ & Protein retention $(\%)^{\star *}$ \\
\hline 0.0 & $1.9017 \pm 0.2567^{\mathrm{a}}$ & $36.41 \pm 0.43^{\mathrm{a}}$ \\
3.0 & $1.9017 \pm 0.2567^{\mathrm{a}}$ & $38.57 \pm 0.90^{\mathrm{ab}}$ \\
6.0 & $2.3175 \pm 0.1709^{\mathrm{b}}$ & $39.55 \pm 3.14^{\mathrm{bc}}$ \\
9.0 & $2.3426 \pm 0.1247^{\mathrm{b}}$ & $42.40 \pm 2.20^{\mathrm{c}}$ \\
12.0 & $2.2407 \pm 0.0621^{\mathrm{b}}$ & $39.71 \pm 2.10^{\mathrm{bc}}$ \\
15.0 & $2.2336 \pm 0.0861^{\mathrm{b}}$ & $39.83 \pm 1.48 \mathrm{a}^{\mathrm{bc}}$ \\
\hline
\end{tabular}

Mean in column with same superscripts are not significantly different $(P>0.05)$.

*Protein efficiency = (the body weight at the end-initial of body weight)/protein intake).

** Retention protein $=$ storing body protein/protein consumption). 
Table 4. Body composition of estuary grouper juveniles (\%) at the end of the experiment

\begin{tabular}{cccccc}
\hline Dietary lipid (\%) & Dry matters (\%) & Protein (\%) & Lipid (\%) & Ash (\%) & Fiber (\%) \\
\hline 0.0 & 35.2 & 64.46 & 10.32 & 16.48 & 3.13 \\
3.0 & 33.2 & 59.79 & 13.2 & 15.04 & 3.25 \\
6.0 & 34.5 & 57.25 & 16.21 & 15.25 & 2.95 \\
9.0 & 32.3 & 55.45 & 21.57 & 13.84 & 3.24 \\
12.0 & 31.7 & 55.73 & 21.28 & 13.88 & 2.98 \\
15.0 & 32.1 & 54.06 & 22.06 & 14.37 & 3.42 \\
\hline
\end{tabular}

\section{CONCLUSION}

Content of dietary lipid affected growth of estuary grouper juveniles. Optimal content of dietary lipid for the best growth of estuary grouper juveniles was $12 \%$.

\section{REFERENCES}

Bligh, E.G. \& W.J. Dryer. 1959. A rapid method of total lipid extraction and purification. Canadian J. Biochem. Physiol., 37: 911-917.

Cacutan, M.R. \& R.M. Coloso. 1997. Growth of juvenille Asian seabass, Lates calcarifer, fed varying carbohydrate and lipid levels. Aquaculture, 149(2): 137-144.

Chu, J.C.W., K.M.Y. Leung, \& R.S.S. Wu. 1996. Nutritional study on the areolated grouper (Epinephelus areolatus) culture in open sea cages. Proc. The Pecon Conference on Sustainable Aquaculture, 11-14 June 1995. Honolulu. p. 79.

Ernullah \& A.K. Jafri. 1998a. Growth rate, feed conversion, and body composition of Calta calta, Labio rohita, and Cirrhinus mrigala fry fed diets of various carbohydrate-to-lipid ration. J. Word Aquacult. Soc., 29(1): 84-91.

Ernullah \& A.K. Jafri. 1998b. Effect of dietary carbohydrate to lipid ratio on growth and body composition of walking catfish (Clarias batrachus). Aquaculture, 161(3): 159-168.

Fair, P.H., W.P. Williams, \& T.I.J. Smith. 1993. Effect of dietary menhaden oil on growth and muscle fatty acid composition of hybrid stripped bass, Morone chrypsops $\times$ M. saxatilis. Aquaculture, 166: 171189.

Fujita, S., T. Watanabe, \& C. Kitajima. 1980. Nutrition quality of Artemia from different location as living feed from viewpoint of essential fatty acids for marine fish. pp 277-290 In G. Personne, P. Sorgelos, O. Roels, and E. Jespers (Eds). The brine shrimp Artemia, vol 3 Universa Press, Belgium.
Gallagher, M.L.. 1997. Growth respone and liver changes in juvenille sunshine bass (Morone chrysops) associated with dietary protein and lipid levels. J. Appl. Aquacult., 6(4): 75-86.

Gangadhara, B., M.C. Nandeesha, T.J. Varghese, \& P. Keshavanath. 1997. Effect of varying protein and lipid levels on growth of rohu, Labio rohita Asian Fish. Sci., 10(2): 139-147.

Giri, N.A., K. Suwirya, \& M. Marzuqi. 1999. Protein, lipid, and vitamin $\mathrm{C}$ requirement of humpback grouper, Cromileptes altivelis juvenile. Indonesian Fisheries Research Journal, 5(3): 38-46

Izquierdo, M.S., T. Watanabe, T. Takeuchi, T. Arakawa, \& C. Kitajima. 1989. Requirement of larvae red sea bream, Pagrus major for essential fatty acids. Nippon Suisan Gakkaishi, 55: 859-867.

Kanazawa, A., S. Teshima, \& K. Ono. 1979 Conversion of linoleic to n-3 highly unsaturated fatty acid in marine fishes and rainbow trout. Bull. Jpn. Soc. Sci. Fish., 46: 1231-1233.

Koven, M.W., A. Tandler, G.W. Kissil, D. Sklan, O. Frieslander, \& M. Harel.1990. The effect of dietary n-3 polyunsaturated fatty acid on growth, survival, and swim bladder development in Sparus aurata larvae. Aquaculture, 91: 131-141.

Owen, J.M., J.W. Adron, C. Middleton, \& C.B. Cowey. 1975. Elongation and desaturation of dietary fatty acid in turbot (Scopthalamun maximus) and rainbow trout. Lipid, 10: 258-271.

Ostrowski, A.C. \& S. Davakaran. 1990. Survival and bioconversion of $\mathrm{n}-3$ fatty acid during early develpment of dolpin (Corypaena hyppuras) larvae fed oil-enriched rotifer. Aquaculture, 89: 273-285.

Salhi, M., M.S. Izquierdo, C.M. Hernandez, M. Gonzalez, \& Fernandez-Palacois. 1994. Effect of lipid and n-3 HUFA levels in microdeits on growth, survival, and fatty acid composition of larval gilthead sea bream (Sparus aurata). Aquaculture, 124: $275-282$. 
Sorgeloss, P., P. Leger, \& P. Laveus. 1988. Improved larval rearing of European, Asian seabass, seabream, mahi-mahi, siganid, and milkfish using enriched diets for rotifer and Artemia. Word Aquacult., 19: 78-79.

Suwirya, K., M. Marzuqi, \& N.A. Giri. 1997. Effect of dietary of squid oil and soybean oil levels on growth and feed efficiency of humpback grouper, Cromileptes altivelis juvenile. Pp. 272-276, In A. Sudradjat, E.S. Heruwati, J. Widodo, \& A. Poernomo (Eds): Proceding of National Seminar on Research and dissemination of Marine and Coastal Culture Technology. Jakarta, December 2, 1999.

Tucker, J.W. Jr., W.A. Lelies, G.K. Vermeer, D.E. Robert Jr, \& P.N. Woodward. 1997. The effect of experimental starter diets with different levels of soybean or menhaden oil on red drum (Sciaenops ocellalus). Aquaculture, 149: 323-339.
Vergara, J.M., L. Ropbiana, M. Izquierdo, \& M.D.L. Higuera. 1996. Protein sparing effect of lipid in the diets for fingerlings of gilthead sea bream. Fish. Sci., 62(4): 624-628

Watanabe, T., C. Kitajima, \& S. Fujita. 1983. Nutritional values of live organisms used in Japan for mass propagation of fish: a review. Aquaculture, 34: 115-143.

Webster, C.D., \& R.T. Lovell. 1990. Response of stripped bass larvae fed brine shrimp from different sources containing different fatty acids composition. Aquaculture, 90: 49-61.

Williems, C.D. \& E.H. Robinson. 1988. Response of red drum to various dietary levels of manhaden oil. Aquaculture, 70: 107-120.

Yano, Y., \& M. Fujii. 1975. Studies on nutrition of red sea bream IX: Effect of n-3 fatty acid supplement in a corn oil diet on growth and feed efficiency. Bull. Jpn. Soc. Sci. Fish., 41: 73-77. 
